\title{
Diversity of boards
}

Book or Report Section

Accepted Version

Kanadli, S. B. and Kakabadse, N. (2019) Diversity of boards. In: Idowu, S., Schmidpeter, R., Capaldi, N. and Zu, L. (eds.) Encyclopedia of Sustainable Management. Springer. ISBN 9783030020064 doi: https://doi.org/10.1007/978-3-030-020064_913-1 Available at https://centaur.reading.ac.uk/87460/

It is advisable to refer to the publisher's version if you intend to cite from the work. See Guidance on citing.

To link to this article DOI: http://dx.doi.org/10.1007/978-3-030-02006-4_913-1

Publisher: Springer

All outputs in CentAUR are protected by Intellectual Property Rights law, including copyright law. Copyright and IPR is retained by the creators or other copyright holders. Terms and conditions for use of this material are defined in the End User Agreement.

\section{www.reading.ac.uk/centaur}

\section{CentAUR}

Central Archive at the University of Reading

Reading's research outputs online 
Idowu, S.O. (Eds.) (2019), Encyclopedia of Sustainable Management, Springer

\section{Chapter Title: Making Board Diversity Work}

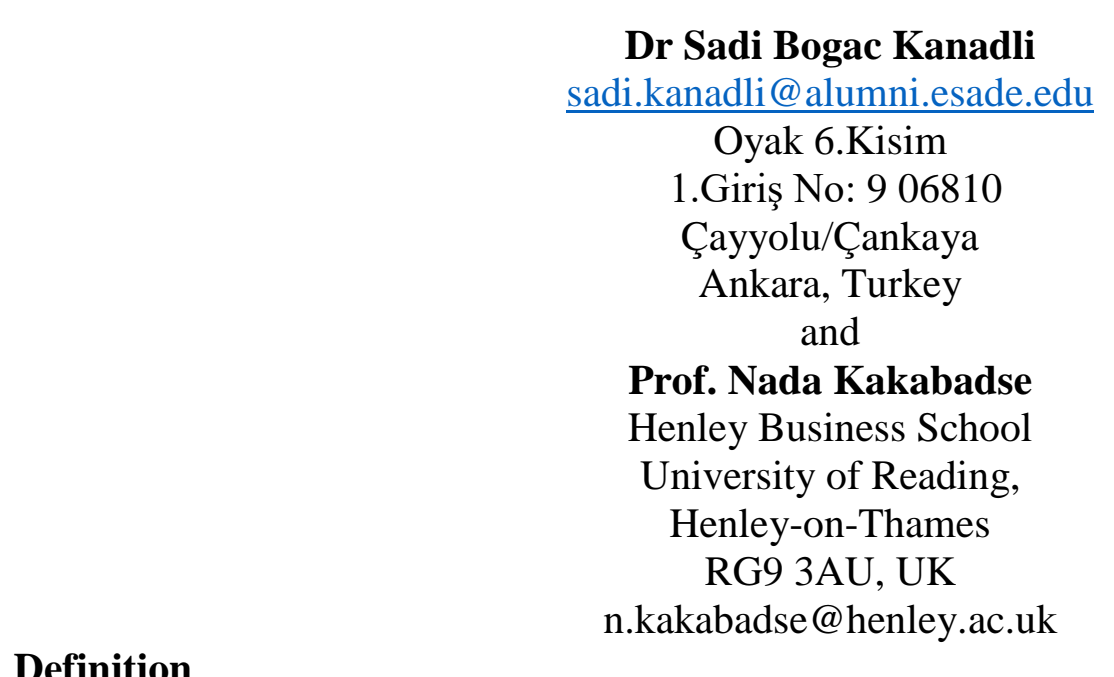

Corporate boards are viewed as upper echelons of their firms, performing critical tasks which of overseeing and influence strategic actions of firms. Whilst monitoring and control tasks are a legal duty of boards, they also participate and contribute to strategy process by providing advice and counsel (advisory tasks), initiating strategic proposals and contributing to the implementation of strategic decisions (strategic tasks) (McKinsey, 2016). "How do we enhance boards' performance?" has become a critical question for scholars, corporate leaders, and policymakers. In answering this question, this chapter focuses on the importance of board diversity with regard to directors' different functional backgrounds, educational backgrounds, and industry experiences. Whether such a variety in the boardrooms benefit strategic actions of firms or not is considered. We draw attention to a greatly neglected issue which has enormous practical importance, the boardroom barriers. There are social, power-related, and cognitive boardroom barriers, which might limit the utilization of board diversity. When these boardrooms barriers are acknowledged, 
a complementary question for scholars, corporate leaders, and policymakers remains, "How do we make board diversity work?".

\section{Introduction}

"Whether and how corporate boards affect organizational outcomes" is still one of the key questions in corporate governance and to some extent strategic management, which has prevailed through decades (Zahra and Pearce, 1989; Krause, 2017). However, recently it seems this inquiry is getting more focused. Diversity is, slightly but steadily, increasing in the boardrooms (Catalyst, 2018; Deloitte, 2019). Corporate leaders are aiming to create diverse boards expecting them to actively participate and contribute to the strategy process (Fairchild, 2015). A recent survey of “The CEO Guide to Boards" by McKinsey (2016) revealed that strategy is, on average, the area boards give most of their attention. Accordingly, "whether and how board diversity influences strategic decisions of firms" has become a timely and important topic which has enormous practical implications. What is board diversity?

Although it is hard to provide a common definition of diversity in boardrooms, diversity simply means "variety" (Milliken and Martins, 1996). Variety in boardrooms is commonly viewed as "variety in directors' knowledge, skills, and professional experience" which is the reflection of directors' different functional background, educational background, and industry experience. Still, variety receives several labels such as "board heterogeneity", "knowledge/information diversity", “cognitive diversity", and "job-related diversity". From a practitioner's eyes variety in boardrooms means availability of a broader pool of relevant information, expertise and increased number of perspectives on the strategic issues at hand (Fairchild, 2015; McKinsey, 2016). Using this 
information and evaluating different perspectives, diverse boards may contribute to the creation of strategic decisions with better quality as well as creativity. How?

Corporate leaders' initiatives in creating variety in boardrooms find considerable support in research. Such that directors' different skills, knowledge, and professional experience enhance boards' ability to successfully perform board tasks (e.g., Kakabadse et al., 2018; Gabaldon et al., 2018) as well as their contributions to strategic decisions (e.g., Haynes and Hillman, 2010). Research also demonstrates that such variety helps firms take decisions with better quality (e.g., Sun et al., 2015) as well as creativity (e.g., Torchia et al., 2018).

However, while board diversity may mean variety in directors' skills, knowledge, and professional experience, at the same time it may also mean separation and disparity (Harrison and Klein (2007). This is a critical specification as it introduces boardroom barriers in the discussions about whether board diversity benefits strategic decisions. For example, increasing numerical representation of women on boards has become a worldwide issue and it seems investments of policymakers, institutional investors as well as NGOs to this end has been paying off (Catalyst, 2018; Deloitte, 2019). Women directors have different values (Eagly, 2016; Post and Byron, 2015) and different knowledge and experience (Hillman et al., 2002; Singh et al., 2008) compared to their male counterparts. From this perspective, an increasing number of women on boards can be expected to increase variety in boardrooms which might positively impact boards' contribution to strategic decisions. Indeed, this is one of the main economic arguments, which find empirical support (e.g., Torchia et al., 2018; Triana et al., 2013), put forward by defenders of an increasing number of women at upper echelons. This line of thinking views gender diversity as a variety.

However, gender diversity means also separation which may result in outgroup - ingroup or "we-they" separation in the boardrooms (Harrison \& Klein, 2007). Gender is generally a salient 
observable among upper echelons - which can lead to the out-group categorization of female directors automatically and instantly (Zhu et al., 2014). Outgroup categorization of women directors in male-dominated boards (Groysberg and Bell, 2013) might limit women directors' contributions to board decision making and, accordingly, strategic decisions (e.g., Huse and Solberg, 2006; Kakabadse et al., 2015). From this perspective, whether and how variety influence strategic decisions can be better understood and explained when social barriers are taken into account.

Likewise, board diversity may also mean variety and disparity. For example, it is not unusual to describe boardrooms as an arena for power games where representatives of major shareholders, directors with friendship ties to CEO, or few males, white, experienced directors dominate boardroom discussions (Finkelstein, 1992). Such asymmetric power held by few in boardrooms results in asymmetric use of resources such as information about financial tables to organizing informal meetings or social gatherings. Those few directors may be enriching variety in the boardroom but also creating high levels of disparity, few benefiting from all resources. How would such power asymmetry would impact utilization of directors' different skills, knowledge, and professional experience? Research suggests that presence of a high-power individual (e.g., Haynes and Hillman, 2010) or power imbalance between directors (e.g., Triana et al., 2013) may hinder boards' contribution to strategic decisions. From this perspective, whether and how variety influence strategic decisions can be better understood and explained when power-related barriers are taken into account.

Considering that diversity may mean variety but also separation and disparity implies that there are social and power-related boardroom barriers which may limit fully use of directors' diverse talent on strategic decisions. However, the scholarly discussions and practices in policy 
and corporate world are still centered on "Should we have more diversity in boardrooms? Does variety in directors' skills, knowledge, and professional experience benefit firms?". Considering research that provides considerable evidence of two "Yeses" to above questions and the presence of boardroom barriers, the two emerging questions are "What are the barriers that limit the use of directors' diverse talent?" and "How do we make board diversity work?".

\section{Key Issues: Boardroom Barriers}

Specifying board diversity as variety, separation, and disparity reveal two boardroom barriers which might limit the utilization of directors' different skills, knowledge, and professional experience onboard tasks and, thus, on strategic decisions. A third boardroom barrier could be added to the list which rests on the idea that directors are expert decision makers with unique knowledge and expertise, but they also have limited cognitive capacities. To be able to generate solutions to reduce or avoid the negative consequences of these boardroom barriers, the first step is to better understand the processes, mechanisms that create these obstacles as well as their negative consequences.

\section{Social Boardroom Barriers}

Social categorization perspective which incorporates social identity and self-identity theories and similarity/attraction paradigm explains the processes that lead to "out-group vs. in-group", "we vs. they" separation in groups. Social categorization perspective posits that individuals create and define their own place in society by categorizing themselves in social groups with some emotions 
and values significant to them regarding the group membership (van Knippenberg et al., 2004). When a certain observable is salient (e.g. gender), out-group categorization tends to be automatic and instant (Gaertner et al., 1989). This leads to intergroup bias which refers to more favorable perceptions of, and attitudes and behavior towards, in-group than outgroup (van Knippenberg et al., 2004). As a result of intergroup bias, evaluations are based on category (e.g., woman vs. man) rather than individual merit; negative attributes are exaggerated and positive ones can be discounted; and permissible behavior of the stereotyped person is clearly constrained (Fiske et al., 1991).

Research has shown how the negative consequences of out-group categorization may impact group dynamics (Zhu et al., 2014). People cooperate more with in-group members compared to out-group members, out-group members are at a significant disadvantage for receiving rewards and positive evaluations compared to in-group members. Out-group members are less likely to be noticed for their positive behaviors, but they are more likely to be blamed for negative results. They are thus more likely to be perceived as less competent, and their information is perceived as less relevant and credible. All in all, diversity's potential cannot be fully realized when some group members face the negative consequences of out-group categorization.

Directors are not immune to social categorization processes (Groysberg and Bell, 2013) and gender, age, ethnicity, education, functional background, top executive experience, and industry background are salient features among directors (Zhu et al., 2014). Based on these women directors can be instantly and automatically categorized as outgroup members by majority male directors. Observable differences (e.g., gender) are at the center of discussions on social categorization processes because they are simply easy to observe and used as heuristic cues by group members to categorize themselves and others into similar in-group members and dissimilar out-group members. 
As a matter of fact, when it is realized that there might be several subgroupings based on aforementioned salient features in the boardrooms, one important issue in the boardrooms emerges demographic faultlines in boardrooms. Demographic faultlines, defined as hypothetical lines that divide a group into multiple subgroups based on the alignment of salient attributes (Lau and Murnighan, 1998).

In this regard, diversity as separation can be better understood when the existence of board demographic faultlines are acknowledged, rather than only focusing on observable salient features. In turn, while board demographic faultlines can explain the subgroupings in boardrooms, outgroupingroup categorizations can be used to explain negative consequences of subgroupings on board performance (Kanadlı et al., 2018; Westphal and Bednar, 2005; Veltrop et al., 2015). One interesting point is that social categorization processes are automatic and instant particularly when the salient feature is observable. However, it should be noted that both board demographic faultlines and negative consequences of outgroup categorization require activation.

Not all demographic fault-lines can be expected to affect board functioning. If board demographic faultl-ines are activated that is demographic fault-lines lead to the perception that the board is split into subgroups, board performance can be expected to be negatively affected (Veltrop et al., 2015). For example, following an M\&As (firm A acquires firm B), the newly formed board can welcome women directors (from firm B) and a subgrouping may be observed based on gender (women directors vs. male directors) in the board of the newly formed organization. Still, it may be in fact subgrouping not based on gender but rather based on new comers vs. hosts that would be perceived by board members as a split. Additionally, if new comers (firm B) are all younger directors than hosts, a strong fault-lines can be detected which can be expected to activate 
perception of subgrouping in the newly formed board. In this stage, social categorization can be thought to occur in the boardroom: "we", "they", "in-group members" or "out-group members".

However, such instant and automatic outgroup categorization do not imply per se that the aforementioned negative consequences of intergroup bias will be realized on outgroups (van Knippenberg et al., 2004). Intergroup bias is typically inspired by threats or challenges to the value or the distinctiveness of group identity. For example, challenges can be social competition for status and prestige, outright derogation and discrimination of the group, and unequal status of subgroups and competitive interdependence between subgroups (van Knippenberg et al., 2004). Following the M\&As example, negative consequences of out-group categorization on newly appointed young directors can be felt when existing tenured directors perceive newcomers behaviors, attitudes as challenge or threat. The ability to operate effectively as a board, sharing unique information and communicating perspectives, becomes more difficult because the board is separated into salient subgroups (Li and Hambrick, 2005).

In sum, without considering the effects of social barriers, any conclusion on the influence of board diversity may be misleading.

\section{Power-related barriers}

The second set of boardroom barriers, which can be once again expected to limit directors' use of their diverse talent, refers to "silencing impact" of power asymmetry felt by low power directors in the presence of high-power individual/s (Pearce and Zahra, 1991). A high-power individual in the boardroom is defined as an individual who has the capability of overcoming resistance in achieving a desired objective or goal (Finkelstein, 1992). A CEO or a chairperson will have such a capability, mostly because of their structural power (Finkelstein, 1992). A CEO, being the leader 
of a firm, as well as a chairperson, being the leader of the board, can be specified as high power individuals in the boardrooms, having structural power.

In boards where there is CEO-duality structure, a CEO might be in the boardroom also as a chairperson, enhancing his or her structural power. However, it is hard to claim that this is the dominant structure across the corporate world (mainly in the US) and, hence, a CEO can only attend board meetings as a chair. Non-duality may be a common practice in boards (particularly in Europe), and a CEO might be in the boardroom as a board member (Kakabadse and Kakabadse, 2007). There might be several reasons for this presentation, although the CEO should not be in the boardroom due to a non-duality structure. For example, a CEO can be the main bridge to or communication channel between the top management team and the board. Moreover, relatedly, a CEO may be the main possessor of firm-specific information as well as the knowledge that is essential for competent board work. In addition, a CEO might personally prefer to be present during board meetings, with the aim of controlling discussions and any possible rivalry to his/her leadership in the firm.

While most discussions on power focus on CEO-duality and thus structural power as the source of power in boardrooms, there are other sources of power that should be considered particularly to understand power asymmetries between directors in boardrooms. Finkelstein (1992) established four types of power: structural, ownership, expert, and prestige, each of which is pertinent to the board of directors. Structural power is rooted in formal position and hierarchical authority and indicates the human capital required for the job. Ownership power is related to equity ownership as well as founder status. A director possesses this power when he/she represents the will of the shareholders. Expert power can develop as a result of having exposure to many different functional areas and breadth of assignments as well as through organizational tenure or years of 
experience, indicating the task and job knowledge of the director. Lastly, prestige power develops from one's institutional environment based on personal prestige or status, reputation, and perceptions of influence (Finkelstein 1992). Prestige power may develop as a result of having a position on one or more boards, serving on influential committees, or having attended elite educational institutions (Finkelstein 1992), suggesting a certain level of knowledge and connections.

Accordingly, a highly tenured director who holds membership of nomination and/or compensation committees and multiple board appointments may as well be a high-power individual in boardrooms. Specifying power asymmetries in boardroom matters as a high-power individual may intentionally or unintentionally exert a "silencing effect" on the directors with lower power (Pearce and Zahra, 1991). In teams with mixed-status individuals, the high-status individuals speak more and tend to exert influence over team discussions (Cleveland et al. 2000). In board context, research shows that a powerful CEO may silence the different voices of directors during board discussions (Haynes and Hillman, 2010). Women directors are considered to have lower power than their male counterparts because they are in general younger, they lack committee memberships and top executive experience, held few or no multiple board appointments (Triana et al., 2013). Triana et al. (2013) show that only when women directors have power in male-dominated boards they can influence strategic decisions.

Power asymmetry in boardrooms can be also linked to age diversity, one of the emerging topics in the corporate world. The main idea is that firms should more and more engage in the use and adaptation of new technologies that mainly built on information technologies and systems which may require the appointment of young directors to boards. New generation younger directors around the age of 40s (compared to average director age of 55-60) are thought to be better 
facilitators for adaptation of the latest technologies. However, it is highly likely that these younger directors may lack the experience as a director, may not held committee memberships or multiple board appointment. Are boards really ready to utilize such low power young directors' talents in the presence of high-power individuals? Although research is limited, up to date the answer seems to be "Yes and No" (Ali et al., 2014).

All in all, without considering the effects of power-related barriers, any conclusion on the influence of board diversity may be misleading.

\section{Cognitive barriers}

It might be surprising to acknowledge that almost for half a century, and to some extent still, the dominant theories of corporate governance have adopted a model of individual who is assumed to rational (Goshal, 2005). In other words, directors are assumed to be superheroes who have all the information to objectively make a decision choice which would maximize shareholders' profit. Of course, there are alternative perspectives taking over which posits that decision makers are only bounded rational with limited information about the decision environment (Van Ees et al., 2009).

Additionally, like other individuals, directors have limited cognitive capacity in processing information. Boundary conditions of information overload occur when individuals reach a point at which they are unable to process any additional information (Tushman \& Nadler, 1978). Not recognizing that a director or board as a whole have limitations in absorbing and processing new information, may result in limited use of directors' diverse talent as those directors may simply reach an information overload (Khanna et al., 2014).

In this regard, may be one of the most important issues in the corporate world is board interlocking directorates. It is also not surprising that having multiple board appointments are seen 
as a source of prestige power among directors. "An interlocking directorate occurs when a person affiliated with one organization sits on the board of directors of another organization." (Mizruchi, 1996:271). Interlocking directorates have been interpreted as an important source of professional experience, timely and relevant information and diverse perspectives (Shropshire, 2010). Therefore, board interlocks reveal beneficial effects on strategic decisions (e.g. Hambrick et al., 2015) as well as diffusion of corporate practices (e.g. Tuschke et al., 2013). As mentioned, board tasks are complex and highly cognitive tasks which are surrendered by ambiguity, uncertainty, and volatility. At how many boards a director can efficiently serve by absorbing unique information, processing this information to produce individual perspective, and actively participate in board discussions about the strategic issues at hand?

Khanna et al (2014, p: 564-65, emphasis added) say; "On the surface, this (board interlocks) suggests a potential paradox whereby a focal firm benefits, on the one hand, from having access to greater amounts of information through its directors' networks, but suffers, on the other hand, because of the high cognitive commitment this places on the directors, which limits their ability to effectively monitor and participate in the strategic decision-making process.". There is also evidence that highly interlocked boards (at least half of the board have more than 3 board appointments) may fail to effectively perform board tasks (Kaczmarek et al., 2014).

In sum, acknowledging social, power-related, and cognitive boardroom barriers, it would be unrealistic to expect utilization of board diversity on strategic actions of firms. Once the negative influence of social, power-related, and cognitive boardroom barriers on the utilization of directors' different skills, knowledge, and professional experience are acknowledged, the following question appears to be "How do we make board diversity work?". Corporate leaders, policymakers as well as board members can take steps in coping with boardrooms barriers. 


\section{Future Directions: Coping with Boardroom Barriers}

\section{Coping with Social Barriers}

Maybe the most important actor in coping with social boardroom barriers is the chairperson. So, the first step would be the deliberate selection of chairperson by corporate leaders. In specifying the leadership attributes of such a chairperson, policymakers and scholars would play a critical role. In some national context, policymakers have been already drawing a chairperson profile such that regulations, as well as best practices of board leadership, requires the appointment of independent chairpersons (Kakabadse and Kakabadse, 2007). Additionally, research shows that a chairperson with a strong leadership efficacy generates an open and safe boardroom and facilitates board discussions in a manner that encourages directors to actively participate and contribute to board discussions (Gabrielsson et al., 2007; Kanadlı et al., 2018). Leadership efficacy consists of certain behaviors of leading discussions, motivating and connecting each board member to best utilize their competencies, formulating proposals for decisions, and summarizing conclusions after board negotiation (Kanadlı et al., 2018). In this regard, a chairperson can be key in benefiting from the variety in the boardroom while coping with the results of out-group categorization in boardrooms (separation).

\section{Coping with Power-related Barriers}

It is common sense that to cope with power asymmetries in boardrooms, power should be decentralized in boardrooms. From this perspective, the selection of new directors can be one important step that might be taken by corporate leaders. Woman directors might be selected not 
only for compliance purposes to legal obligations (gender quota is implemented in 2008 in Norway) but also for their competencies that may be a source of ownership, expert, and prestige power. Additionally, newly appointed woman directors can be also simultaneously appointed to important committees which would also increase women directors' power in boardrooms. Even policymakers may have a stake on this. Making mandatory non-financial disclosures on the gender profile of boards might maintain more transparency in board nominations which might provide a source of prestige power for newly appointed woman directors.

Additionally, balancing of power can be complemented, or replaced in case of power balancing turns into a problem, by specifying board norms which would aim at regulating the flow of resources to all directors irrespective of their level of power. For example, there might be a clear division of labor in board functioning, specific rules about decision making culture that can be characterized with inclusiveness, collaboration, and openness. It might be possible for a director to personally reach a manager to be able to get extra firm tacit knowledge without consulting the CEO or high-power individual who creates disparity in the boardroom. Board evaluations may also work in the same direction, neutralizing the impact of power asymmetries, by incorporating individual evaluations and evaluations of board work as a whole. Policymakers can play a critical role by requiring disclosures of board evaluations if not disclosed voluntarily by corporate leaders. All in all, decentralizing power in boardrooms and/or specify board norms about accessing resources and board decision making can be key to utilize benefits of variety in boardrooms while coping with power asymmetries (disparity).

\section{Coping with Cognitive Barriers}


Once again, corporate leaders may be careful in setting the criteria for selection of new directors, limiting the number of board-interlocks a candidate director or chairperson or even CEO may have. The search firm Stuart Spencer documented a recent trend (2013) that more and more companies prohibit their CEOs or other executives from sitting on other firms' boards. As a matter of fact, policy makers are already in action. It is not only companies that developed a negative attitude against multiple board appointments but also policy makers (e.g., UK Combined Code 2008; UK Corporate Governance Code 2010; Walker Review, 2009).

In addition to limiting information processing demands of directors from other firms, how relevant information shared by directors before board meetings can be also managed by the use of IT systems. Such that instead of reading pages of reports, book records, analysis, a specific IT system can be designed to serve the directors' need, providing refined, tacit information out of the available vast amount of data and information. Lastly, a number of board meetings and the length of board meetings might be carefully set and chairperson might take the responsibility in observing whether information overload is reached during board meetings. In sum, limiting a number of board appointments, benefiting from IT systems for refining the vast amount of information, and managing number and length of board meetings can be key to utilize benefits of variety in directors' diverse talents without causing information overload for each director as well as a board as a whole.

\section{Summary}

Although there has been slow but steady progress towards bedroom diversity, it is, unclear to what extend diverse board makes use of available talent in the boardroom. It all depends on the Chairperson's skill and capability to harness the benefits of diversity in the boardroom. Board 
appointments and dynamics remain largely a black box as not much research have been done on the selection and appointment process in capturing diverse director's experiences as directors. It is usually the chairperson, whospearheaded the process of making the board a place that value diversity of functional background, educational background, and industry experience. However, many boards are also recognizing the distinction between diversity and inclusiveness. Where diversity is counting the numbers, the inclusiveness is making the numbers count. In order to be sustainable, Boards need to improve on both dimensions and in particular overcome boardroom barriers, whether it is social barriers, power-related barriers or cognitive barriers in order to harness the talent of the diverse board...

\section{Cross-References}

- Diversity of Boards

- Governance

- Sustainability of Boards

\section{References:}

Ali, M., Ng, Y. L., \& Kulik, C. T. (2014). Board age and gender diversity: A test of competing for linear and curvilinear predictions. Journal of Business Ethics, 125(3), 497-512.

Catalyst. 2018. Women on Corporate Boards. Accessed at (13/02/2019) https://www.catalyst.org/knowledge/women-corporate-boards

Deloitte. 2019. Missing Pieces Report: The 2018 Board Diversity Census of Women and Minorities on Fortune 500 boards. Accessed at (13/02/2019) 
https://www2.deloitte.com/content/dam/Deloitte/us/Documents/center-for-boardeffectiveness/us-cbe-missing-pieces-report-2018-board-diversity-census.pdf

Eagly, A. H. 2016, "When Passionate Advocates Meet Research on Diversity, Does the Honest Broker Stand a Chance?.” Journal of Social Issues, 72(1): 199-222.

Fairchild, C., 2015. How Macy's quietly created one of America's most diverse boards. Fortune.

Finkelstein, S. (1992). Power in top management teams: Dimensions, measurement, and validation. Academy of Management Journal, 35(3), 505-538.

Fiske, S. T., Bersoff, D. N., Borgida, E., Deaux, K., and Heilman, M. E.1991, "Social science research on trial: Use of sex stereotyping research in Price Waterhouse v. Hopkins.” American Psychologist, 46(10): 1049.

Gabaldon, P., Kanadli, S. B., and Bankewitz, M. 2018. How does job-related diversity affect boards' strategic participation? An information-processing approach. Long Range Planning, 51: $937-952$.

Gabrielsson, J., Huse, M., and Minichilli, A. 2007. Understanding the leadership role of the board chairperson through a team production approach. International Journal of Leadership Studies, 3: 21e39.

Gaertner, S. L., Mann, J., Murrell, A. and Dovidio, J. F. 1989, "Reducing intergroup bias: The benefits of recategorization.” Journal of Personality and Social Psychology, 57(2), 239.

Ghoshal, S. (2005). Bad management theories are destroying good management practices. Academy of Management learning \& education, 4(1), 75-91.

Groysberg, B. and Bell, D. 2013, "Dysfunction in the boardroom." Harvard Business Review, 
91(6): 88-97.

Hambrick, D. C., Misangyi, V. F., \& Park, C. A. (2015). The quad model for identifying a corporate director's potential for effective monitoring: Toward a new theory of board sufficiency. Academy of Management Review, 40(3), 323-344.

Harrison, D.A., Klein, K.J., 2007. What's the difference? Diversity constructs as separation, variety, or disparity in organizations. Academy of Management Review 32: 1199-1228.

Haynes, K.T., Hillman, A., 2010. The effect of board capital and CEO power on strategic change. Strategic Management Journal 31: 1145-1163.

Hillman, A. J., Cannella, A. A., and Harris, I. C. 2002, "Women and minorities in the boardroom: How do directors differ?” Journal of Management, 28: 747-763.

Huse, M., and Grethe Solberg, A. 2006, “Gender-related boardroom dynamics: How Scandinavian women make and can make contributions on corporate boards." Women in Management Review, 21(2): 113-130.

Kaczmarek, S., Kimino, S., \& Pye, A. (2012). Board task-related faultlines and firm performance: A decade of evidence. Corporate Governance: An International Review, 20(4), 337-351.

Kaczmarek, S., Kimino, S., and Pye, A. 2014), “Interlocking directorships and firm performance in highly regulated sectors: the moderating impact of board diversity." Journal of Management and Governance, 18(2): 347-372.

Kakabadse, N. K., and Kakabadse, A. P. 2007, “Chairman of the board: demographics effects on role pursuit.” Journal of Management Development, 26(2), 169-192. 
Kakabadse, N. K., Figueira, C., Nicolopoulou, K., Hong Yang, J., Kakabadse, A. P., and Özbilgin, M. F. 2015, “Gender diversity and board performance: women's experiences and perspectives.” Human Resource Management, 54(2), 265-281.

Kakabadse, A., Goyal, R., \& Kakabadse, N. (2018). Value-creating Boards-Diversity and Evolved Processes. Journal of Creating Value, 4(1), 22-41.

Kanadlı, S. B., Torchia, M., \& Gabaldon, P. (2018). Increasing women's contribution on board decision making: The importance of chairperson leadership efficacy and board openness. European Management Journal, 36(1), 91-104.

Khanna, P., Jones, C. D., and Boivie, S. 2014. Director human capital, information processing demands, and board effectiveness. Journal of Management, 40: 557-585.

Krause, R. 2017. Being the CEO's boss: An examination of board chair orientations. Strategic Management Journal, 38: 679 - 713.

Lau, D. C. \& Murnighan, J. K. 1998. Demographic diversity and faultlines: The compositional dynamics of organizational groups. Academy of Management Review, 23: 325-340.

Li, J., \& Hambrick, D. C. (2005). Factional groups: A new vantage on demographic faultlines, conflict, and disintegration in work teams. Academy of Management Journal, 48(5), 794813.

McKinsey. 2016. The CEO Guide to Boards. Accessed 05/02/19. url: http : / www.mckinsey.com/ business - functions / strategy - and -corporate-finance/ourinsights/tapping-the-strategic-potential-ofboards.

Milliken, F.J., Martins, L.L., 1996. Searching for common threads: Understanding the multiple 
effects of diversity in organizational groups. Academy of Management Review 21: 402-433.

Mizruchi, M. S. 1996. What do interlocks do? An analysis, critique, and assessment of research on interlocking directorates. Annual Review of Sociology, 22: 271-298.

Pearce, J. A., \& Zahra, S. A. (1991). The relative power of CEOs and boards of directors: Associations with corporate performance. Strategic management journal, 12(2), 135-153.

Post, C., and Byron, K. 2015, "Women on boards and firm financial performance: A metaanalysis." Academy of Management Journal, 58(5): 1546-1571.

Rindova, V. P. 1999, "What corporate boards have to do with strategy: A cognitive perspective." Journal of Management Studies, 36: 953-975.

Shropshire, C. (2010). The role of the interlocking director and board receptivity in the diffusion of practices. Academy of Management Review, 35(2), 246-264.

Singh, V., Terjesen, S., and Vinnicombe, S. 2008, "Newly appointed directors in the boardroom:: How do women and men differ?.” European Management Journal, 26(1), 48-58.

Sun, S. L., Zhu, J., and Ye, K. 2015, “Board Openness During an Economic Crisis.” Journal of Business Ethics, 129: 363-377.

Torchia, M., Calabrò, A., Gabaldon, P., and Kanadli, S. B. 2018. Women directors contribution to organizational innovation: A behavioral approach. Scandinavian Journal of Management, 34: $215-224$.

Triana, M. D. C., Miller, T. L., and Trzebiatowski, T. M. 2013. The double-edged nature of board gender diversity: Diversity, firm performance, and the power of women directors as predictors of strategic change. Organization Science, 25: 609-632. 
Tuschke, A., Sanders, W. G., \& Hernandez, E. (2014). Whose experience matters in the boardroom? The effects of experiential and vicarious learning on emerging market entry. Strategic Management Journal, 35(3), 398-418.

Tushman, M. L., \& Nadler, D. A. 1978. Information processing as an integrating concept in organizational design. Academy of Management Review, 3: 613-624.

Van Knippenberg, D., De Dreu, C. K., and Homan, A. C. 2004, "Workgroup diversity and group performance: an integrative model and research agenda.” Journal of Applied Psychology, 89: 1008-1022.

Veltrop, D. B., Hermes, N., Postma, T. J., \& de Haan, J. (2015). A tale of two factions: Why and when factional demographic faultlines hurt board performance. Corporate Governance: An International Review, 23(2), 145-160.

Westphal, J. D., \& Bednar, M. K. (2005). Pluralistic ignorance in corporate boards and firms' strategic persistence in response to low firm performance. Administrative Science Quarterly, 50(2), 262-298.

Zajac, E. J., \& Westphal, J. D. (1996, August). Director reputation, CEO/board power, and the dynamics of board interlocks. In Academy of Management Proceedings (Vol. 1996, No. 1, pp. 254-258). Briarcliff Manor, NY 10510: Academy of Management.

Zahra, S. A., \& Pearce, J. A. (1989). Boards of directors and corporate financial performance: A review and integrative model. Journal of management, 15(2), 291-334.

Zhu, D. H., Shen, W., and Hillman, A. J. 2014, "Recategorization into the In-group The Appointment of Demographically Different New Directors and Their Subsequent Positions on Corporate Boards.” Administrative Science Quarterly, 59 (2): 240-270. 
